\title{
The Responsibility Of A Shop House Tenant (Ruko) If Demage Happen When The Rental Agreement Ends
}

\section{Minstyn Tambunan}

Sumatera University Faculty Of Law. E-mail: minstyntambunan99@gmail.com

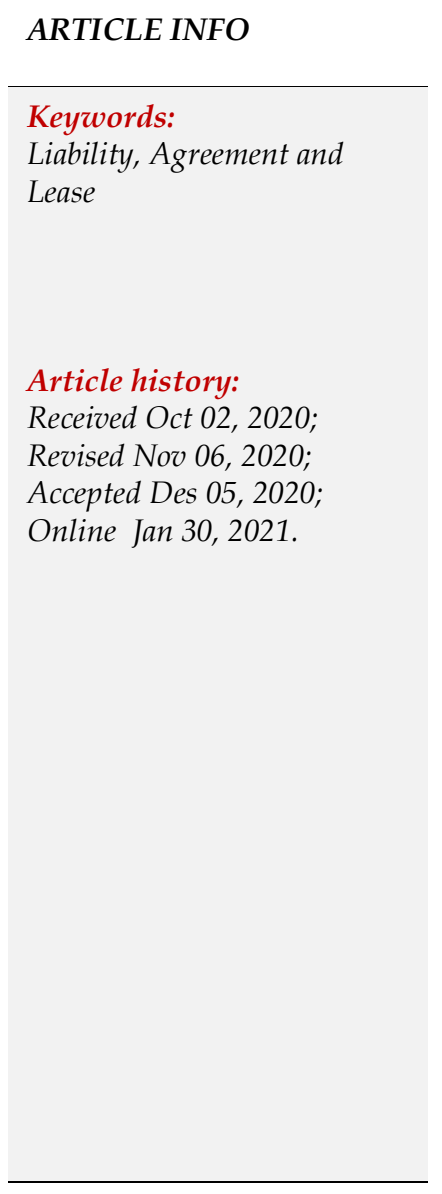

\begin{abstract}
In the era of increasing population growth, the need for housing is also increasing, but the area of land needed is decreasing, for that, the way to overcome this is to build houses or shop houses for rent. However, not all people can afford to build these houses or shophouses. Therefore, a house or shophouse rental agreement was made. The problem in this study is how the procedure for a shop house rental agreement occurs between the parties, what are the rights and obligations of the parties in the shophouse rental agreement and what is the responsibility of the shop house tenant if it occurs. damage when the lease agreement expires. This research was conducted in the city of Medan.This research is descriptive. The approach method used is the normative juridical method and the empirical juridical method. The data used are primary data and secondary data. Data collection methods are library data and field studies. Data were collected using a questionnaire. After collecting the data, it was analyzed qualitatively. The shophouse rental agreement entered into by the parties begins with an agreement which is then included in a contract that they have drawn up themselves. The shop owner's obligations are to provide shop-houses that are suitable for use, hand over shop-keys, provide supporting facilities (for example: water, PAM, electricity and telephone), not to lease back to other parties during the current lease period, ask the tenant whether this is done extension of the lease at the shophouse and submit supporting documents in the agreement. Meanwhile, the tenant's obligation is to pay the rent for the shop, to maintain the condition of the shop properly, to pay the budget for the tenant's fees (for example: water, electricity and telephone). If there is damage to the shop at the time the lease agreement ends
\end{abstract}

This is an open access article under the CC BY-NC license.

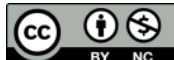

\section{Introduction}

Nowadays, the need for housing and business is very urgent, which is increasing every year in accordance with the increasing population growth. The existence of high population growth resulted in many people who lack housing and places of business. The rapid population growth has resulted in the need for residential houses and business houses (shop houses/ruko) also increasing.

One way to overcome the need for residential houses and shop houses is to increase the number of residential houses and the number of shop houses that are used as places for business as well as residences. To increase the number of houses or shophouses, it is not possible for all people to build the building. This is due to the economic level of different layers of society. 
For people whose economic level is able to build houses or shop houses, they can rent out their houses or shop houses to people who need it, or in this case people from the lower middle class who cannot afford to buy a house or build their house. themselves, so they prefer to rent a house or shophouse which is more affordable for them.

Thus, a rental activity arises between the parties, namely the tenant of the house or shophouse and the party who rents the house or shophouse. The lease agreement entered into by the parties is one of the forms of legal relationships that are currently often carried out by a person in order to fulfill his interests or needs.

A lease agreement made or carried out by several parties or persons indicates that everyone who enters into the agreement is ready to carry out his obligations as agreed. As is well known, in the case of a lease agreement, each party has its own rights and responsibilities, in which these rights and responsibilities must be fulfilled by the parties who enter into the agreement.

Lease agreement is one form of special agreement that is often encountered in everyday life. It is well known that every human being always has complex interests, where humans are always trying to be able to achieve their every need. One way is to establish legal relations with other humans. One of the various forms of legal relations is entering into a lease agreement. Leasing, like other agreements in general, is a consensual agreement, meaning that the agreement is valid and binding on seconds of reaching an agreement between the two parties.4 So as regulated in Article 1548 of the Civil Code.

\section{Method}

This writing was carried out with a normative juridical approach and an empirical juridical approach. The normative juridical approach is intended to conduct an assessment of civil law and the application of civil law as a means of civil law policy in the context of a shop-house rental agreement in Medan City.

The empirical juridical approach is intended to conduct research on the existence of civil law in Indonesia and its application to law enforcement in Indonesia.

The method used in writing this thesis uses two methods, namely:

a. The method of collecting data is by means of library research, namely by studying and systematically analyzing books, articles, newspapers or newspapers, the internet and mass media.

b. By means of field studies (Field research), namely by conducting direct interviews with the parties concerned or by conducting a questionnaire or by using a questionnaire.

\section{Analysis And Results}

\subsection{Meaning Of Agreements}

Book III of the Civil Code regulates engagement, which includes agreements. To get an understanding of the terms used, namely engagement and agreement, it must be carefully examined the meaning of the words above.

The terms above are derived from the Dutch language, namely the term for the engagement, namely "Verbintenis", while for the term agreement or agreement it is "Overeenskomst". The word agreement shows the meaning, that the parties in the agreement to be held have agreed on what they agreed in the form of the promised promises. Meanwhile, the word agreement shows the meaning that the parties to an agreement also mutually agree on everything that is agreed upon.17 The use of this term creates disagreements among legal experts and this is a problem in formulating agreements and engagements. 


\section{a. Valid Terms of Agreement}

An agreement is said to be valid if the agreement fulfills the conditions determined by law so that it is recognized by law. The Civil Code regulates the conditions needed for the validity of the agreement in Book III Chapter 2, the second part (Article 1320-1337).

Article 1320 of the Civil Code states that the terms of the agreement are:

1) Agree with those who bind themselves

2) Speak to make a pact

3) About a certain thing.

4) A lawful reason

Indonesian legal experts generally argue that if the objective conditions are not met, then the agreement is null and void. Meanwhile, in the case of subjective not being fulfilled, the agreement is not null and void but can be requested for its cancellation. In other words, this agreement is valid or binding as long as it is not canceled (by a judge) at the request of the party entitled to request the cancellation.

\section{b. Definition of Lease Agreement}

In everyday life, people often find rental agreements, especially those relating to buildings, this is made possible because of the popularity of humans and the disproportionately wide available area, where the number of people to meet their daily needs is increasing while nature is a place where people can live. Humans in fulfilling their lives remain homeless. Therefore, one side of the law, especially contract law, makes a definite classification of this lease agreement. In the legal system, this lease agreement is an agreement which by law is given a certain name.

\subsection{Shop Tenant Liability If Any Damage Happens During The Rental Agreement Rent Ends}

a. Procedure for the Ruko Lease Agreement between the Parties

In terms of discussing the procedure for the shophouse rental agreement that occurs between the parties, it must first be understood the parts contained in the lease agreement, for example the terms and validity of the agreement.

As previously discussed, in general, according to ordinary people's thinking, that shophouse is a house whose owner uses the house to become a house that has dual functions or not just a house but also a place of business but still does not disturb people and streamlines time in try.

Meanwhile, in terms of agreements, just like any other agreement, the lease agreement is one form of special agreement that is often encountered in everyday life. It is well known that every human being always has complex interests, where humans are always trying to be able to achieve their every need. One way is to establish legal relations with other humans. One of the various forms of legal relations is entering into a lease agreement.

As it is known that the lease agreement is one example of a consensual agreement, meaning an agreement in which the agreement between the two parties has been reached to enter into an agreement. This agreement already has binding legal force, which is written in Article 1338 of the Civil Code. Book III of the Civil Code regulates engagement, which includes agreements. To get an understanding of the terms used, namely engagement and agreement, it must be carefully examined the meaning of the words referred to.

The shophouse rental agreement has a procedure for making an agreement that is being or is about to be implemented. In research conducted, in general, the procedure for a lease agreement is made by both parties and each party must know each other the meaning and purpose and objectives of the contents of the agreement they have made. In making the 
contents of the lease agreement, the parties usually make it based on the results of their own thoughts, but there are also some who combine the results of their thoughts with the laws they know. The contents of the agreement include:

1) Regarding the provision that the tenant must maintain or maintain the condition of the house as well as possible.

2) About the provisions regarding the rental price to be paid by the tenant

3) About the rental period that has been agreed by both parties

4) About the rights and obligations of each party that must be obeyed by each party

5) Contains the settlement if there is a dispute between the parties that occurs when the rental period is still ongoing or has ended.

After the agreement has been agreed on the contents of the agreement they have made, and each party has signed and included the stamp duty in their agreement, then indirectly the agreement has been running because it has been valid in its implementation. And each party has carried out the procedures in the shop rental agreement.

\section{b. Rights and Obligations of the Parties in the Ruko Lease Agreement}

The lease agreement that has been agreed, in which there is a set of rights and obligations of each party. The provisions regarding these rights and obligations have been written in the lease agreement which has been agreed by each party.

As previously explained that the rights and obligations are reciprocal actions, meaning that the rights of one party are the obligations of the other party, and vice versa, the distribution of rights and obligations of each party obtained from several sources is as follows: :

1) Obligations of the lessor or owner:

a) Providing a shop that is suitable for use

b) Handing over the shop keys

c) Provide supporting facilities, for example: PAM Water, Electricity and Telephone

d) Do not lease back to other parties within the current lease period

e) Asking the tenant whether the rental extension has been carried out at the shophouse

f) Submit supporting documents in the agreement, for example: draft agreement, payment for electricity, PBB and IMB Apart from the party who rents out, the obligations of the lessee are also obtained.

2) Obligations of the Tenant:

a) Paying the rent for the shophouse Keeping the shop in good condition

b) Paying rent dues budget money, for example: water, electricity and telephone

c) And others

The results obtained from the field above indicate that the parties have entered into an agreement in accordance with the Civil Code and what is regulated therein. In the case of the renting party, they have implemented the provisions of Article 1550 of the Civil Code and the party whose tenant has carried out in accordance with Article 1560 of the Civil Code, so that the next step is how the parties carry out or carry out or comply with the agreement they have made and agreed that they obtain rights arising from the obligations of each party.

c. Ruko Tenant Liability If Damage Occurs When the Lease Agreement Expires.

In the rental agreement, it is usually determined when the agreement ends, which states that what is specified in the agreement regarding the expiration period of the lease agreement and additional time for the tenant to vacate the rented shophouse. From the data collection carried out, almost all shophouse owners and tenants stated that the rental of the shophouse ended when the rental period ended in accordance with the rental period in the agreed agreement. However, there are also those who add an explanation of exactly when the rental period ends. 


\section{Conclusion}

The procedure used by the parties begins with a word of agreement from both of them, which is then included in a contract that they make themselves. In the contract they make must be stamped and affixed by the signatures of both parties.

Rights and obligations are reciprocal actions. The obligations of the shop owner include providing suitable shophouses, handing over shop keys, providing supporting facilities (for example: water, PAM, electricity and telephone), not renting back to other parties during the current lease period, asking the tenants whether to extend the lease at the shophouse and submit supporting documents in the agreement (eg: draft agreement, electricity payment, PBB and IMB). Apart from the party who rents out, there are also obligations from the tenant, including: paying the rent for the shop, keeping the shop in good condition, paying the tenant's dues and others.

If there is damage to the shophouse at the end of the lease agreement, then those who are responsible are adjusted according to their agreement whether both parties or only the tenant must be responsible for the damage.

\section{References}

Abdulkadir Muhammad, 2000, Indonesian Civil Law, PT. Citra Aditya Bakti, Bandung.

Badrulzaman, Mariam Darus, 2001, Compilation of Engagement Law, PT. Citra Aditya Bakti, Bandung.

Andie A. Wicaksono, 2005, Managing Realestate Investment, Independent Publisher, Jakarta.

2006, Variety of Ruko Designs (Rumah Toko), Independent Publisher, Jakarta.

Denys, Lombard, 1996, Nusa Java, Cross Culture Part 2, Asian Network, Le Carefour Javanais, Esai D'hostaire Globale II, Lex Resaux Asiatiques, Gramedia, Jakarta.

Harahap, M Yahya, 1986, Aspects of Covenant Law, Alumni, Bandung.

HS, Salim, 2010, Theory Development in Legal Studies, PT. Raja Grafindo Persada, Jakarta.

Jon, Lim, The Origin Of The Singapore Shophouse, PP, 23-31in Architecture Journal1990, School Of Architecture, National University Of Singapore.

Komariah, 2008, Civil Law, UMM Press, Jakarta.

Masjchon, Sri Soedewi, 1980, Security Law in Indonesia Basics of Security Law in Indonesia, Liberty, Yogyakarta.

Muljadi, Kartini and Gunawan Widjaja, 2003, Associations in General, Raja Grafindo Persada, Jakarta.

Prodjodikoro, R. Wirjono, 1986, Principles of Agreement Law, PT. Bale Bandung, Bandung. 1987, Law of Contracts and Engagements, Pradya Paramita, Jakarta.

Satrio, J, 1993, Security Law, Property Security Rights, PT. Citra Aditya Bakti, Bandung

Setiawan, R, 1987, Principles of Engagement, Bina Cipta, Bandung Subekti, R, 1987, Covenant Law, PT. Intermasa, Jakarta 1995, Various Agreements Printed X, Citra Aditya, Bandung 
Contract Law Proficiency Training Lecturer Team, 2005, Contract Law Education and Training Textbook Andalas University, Padang

Big Indonesian Dictionary, 1990, Jakarta, Balai Pustaka Phonix Pocket Dictionary New Edition, 2008, Jakarta Dutch-Indonesian Legal Dictionary, 2005, Jakarta, Sinar Graphi.

Excerpt from the book: JD Benjamin (1996.63), taken from a thesis paper from Petra Christian University, Houses and Shops, accessed on October 11, 2012 at 22:41 WIB.

Budhivaya-nlc-blogspot.com/2010/11/law-agreement-lease-a-house- chapter-15.html.com, Budhivaya, Legal Market for House Rental Agreements, accessed on October 11, 2012 at 22:41 WIB.

http://id.wikipedia.org/wiki/place_tinggal, accessed on March 18, 2013, 22.15 WIB

http://penelitian Hukum.org/tag/pengertian_place_usaha/, accessed on 18 March 2013, 22:15 WIB.

Http://www.anneahira.com/design-rumah-toko-1848.htm, Anne Ahira, \Creating an Effective Shophouse Design. accessed on October 12, 2012, at 15.00 WIB 